\title{
Where China Meets Latin America: Implications for Economic Growth
}

\author{
Jaime Ortiz \\ A.R. Sánchez School of Business \\ Texas A\&M International University \\ Laredo, USA \\ jortiz@tamiu.edu
}

\author{
Haibo Wang \\ A.R. Sánchez School of Business \\ Texas A\&M International University \\ Laredo, USA \\ hwang@tamiu.edu
}

\begin{abstract}
This paper examines the sources of economic growth for a group of Latin American countries in relation to their export performance in China. The analytical framework is based on an extended normalized quadratic profit function. The ensuing econometric results confirm that a favorable export record with China represents a positive source of growth for Latin America. However, it also creates long-run dependability conditions in terms of reduced prices and thinner profits that weaken its growth capacity. Latin American countries must seek product diversification away from their current commodity base and aggressively climb up the value chain to remain competitive worldwide.
\end{abstract}

Keywords-trade dynamic; international business; competitive equilibrium; profit function

\section{INTRODUCTION}

The dependency theory, advanced separately by Singer and Prebisch in the early fifties, attempts to explain a recurring terms-of-trade variation that takes place when peripheral countries rely on low-value exports of primary goods to and high-value imports of manufactured goods from countries of the center. Such a theory was rapidly challenged on political as well as economic grounds based on whether or not a deterioration or improvement of their terms-of-trade was indeed taking place. Regardless, it gave Latin America license to wall itself off behind protective barriers to lessen the persistence of cyclical shocks while pursuing an allegedly superior strategy of self-reliant long-term development [1]. The import substitution industrialization strategy required countries to isolate themselves to reshuffle their productive capacity toward a diversified production of durable consumer goods. Nowadays, the region faces another kind of dependency as a growth-generating mechanism but with respect to a completely unforeseen geographical and political actor.

Competition between China and Latin America is relatively modest compared to the one between Asia and the United States. However, it is gradually gaining momentum. China exerts a sustained demand for Latin American goods that represents approximately 35 percent of its overall regional trade balance[2]. Such a large market share has become the leading factor driving world commodity prices to unprecedented levels and pushing Latin American economies forward. China and Latin America have mutually benefitted

The contribution of these works to understand the impact on selected economies triggered by the rapid expansion of foreign trade shown by China is unquestionable. However, none of them explicitly identifies nor quantifies the underlying sources of growth for Latin American countries after their excessive reliance in exporting a narrow despite a striking pattern of comparative advantage reversal between an industrialized nation and developing countries $[3,4]$. The former imports a wide range of low-end manufactured and tech goods while the latter shows an insatiable appetite for primary resources for its large domestic industry [5]. A plausible observation is that China is squeezing out Latin America from the world markets and jeopardizing its ability to develop technological innovations that will generate long-term growth[6]. Efforts to expand Latin America's export share in China to non-traditional agricultural commodities or carve market niches for brand name goods have also proven difficult due to low-value content perishable products, substantial taste differences, and long travel distances to cover [7]. However, the more worrisome aspect for Latin America, derived from an excessive export-oriented exposure, is its inability to conveniently decouple from China when needed.

Various streams of empirical research have studied the implications of asymmetric trade within the context of long-run economic growth in developed and developing countries.Easterly et al. [8] model macroeconomic differentials among Latin American countries to endorse the importance of policy reforms on maintaining their historical rates of economic growth. Akin and Kose [9] disclose the more intensive nature of spillovers between developed and emerging economies using panel regressions. Their findings suggest that an increasing degree of diversification, high growth rates, and greater importance in the global economy have allowed countries like China to evolve into a multidimensional interdependence stage. Hanson and Robertson [10] use a gravity trade model to conclude that the impact of China's economic growth on the demand for exports in manufacturing oriented Latin American countries is relatively modest. In contrast, Iacovoneet al. [11] evaluate the effects of low wages and competitive pressures exerted by China on Mexican manufacturing firms at the product level. Their conclusion is that a rise in Chinese exports has forced them to shrink, exit, or alter existing production patterns regardless of their degree of sophistication, market orientation, and efficiency levels. Lastly, Bloom et al. [12] examine the role of Chinese import competition on patenting, research and development, and total factor productivity. Their results indicate that technical change has upgrading and positive effects towards more innovatively advanced firms.

assortment of primary commodities to China. This paper addresses those shortcomings. First, it empirically links the sustainability of their economic growth to factor endowments, technology, and the real exchange rate. Second, it considers the most salient trading partners such as Argentina, Brazil, Chile, Mexico, Peru, and Venezuela. These countries 
represent more than 90 percent of all trade with China and enjoy a strategic political position in terms of their regional influence. Third, it departs from the conventional body of $\mathrm{ad}$ hoc regression models or general equilibrium frameworks to measure trade effects on growth performance. Instead, it uses a quadratic profit function to estimate the magnitude of the expansionary relationship between China and Latin America between 1984 and 2008. The analysis is structured in four sections. The first provides a snapshot of the trade dynamics between Latin America and China. The subsequent sections present the economic growth model being used, followed by a discussion of the data set and the empirical findings before presenting some concluding remarks.

\section{TRADE DYNAMICS BETWEEN LATIN AMERICA AND CHINA}

Latin America underwent ambitious stabilization programs and structural reforms in the late eighties and early nineties. These macroeconomic policies and governance processes led to a 3.3-percent rate of economic growth explained mainly by its external sector [13]. Feenstra and Rose [14] used a semi-parametric methodology to rank both countries and commodities according to an exporting order consistent with the product cycle hypothesis. However, Latin American countries did not experience such rapid convergence in terms of productivity levels and growth rates and ended up exporting just what they could. Over time, few of them diversified their exportable basket while others were left with no other option than to respecialize in a handful of commodities despite the greater degree of openness, access to state-of-the art technologies, and additional property rights they enjoy today [15]. The end results were substantial welfare implications associated with terms-of-trade-driven effects.

China started its political transition in 1978 through the acceleration of neoliberal reforms as part of a profound economic restructuring while still maintaining the communist-style rhetoric [16]. These reforms encouraged foreign investment in special economic zones along the coastal line where the State promoted industrial development through facilities, public services, and housing centers for workers, converting China into the largest world manufacturer [17]. A conveniently misaligned exchange rate coupled with tariff and quota reductions allowed it to increase its share of the trade world. China currently produces approximately one third of all manufactured goods in the world to account for nearly 10 percent of world exports and 12.5 percent of world imports. Recently, it became the largest trading nation after Germany and the United States[18].

The inclusion of China into the World Trade Organization in 2001 further remapped the entire trade and foreign direct investment scenarios [19]. Liberalization policies contained in its accession protocol added certain vulnerability to external factors accompanied with greater domestic market competitiveness. Nevertheless, China still managed an impressive and consistent annual growth rate of almost 10 percent in the last three decades. Soloagaet al. [20] suggest that such a remarkable economic and industrialization resurgence presents more challenges than opportunities to its Latin American trading partners. In fact, Jenkins et al. [21] highlight the incapacity of the region to alleviate poverty through cheaper prices for consumers and increase government spending in social causes as a result of its widespread export surge of labor-intensive agricultural products. On the other hand, Gottschalk and Prates [22] pinpoint Latin America's lack of vision for keeping up with a reasonable investment rate, especially in infrastructure, in virtue of ongoing upward price trends associated with a heavy concentration on minerals resources.

The exponential type of trend that picks up around 2000 is obvious for every single country despite the fact that each one of them had established diplomatic relations with China in the early seventies. Latin American exports to China grew at an annual average rate of 19.9 percent within that period, which was 2.2 percent slower than its imports growth. The signing of country-specific free trade agreements explains the favorable commercial increase in the following years. Brazil and Chile are the biggest exporters, leaving Argentina at midpoint with respect to the remaining countries. Greater competitiveness and increased demand have allowed them to expand their market share at the expense of a redirection from other export markets.

The imports from China to the six Latin American countries in US billions from 1984 to 2008 rising at an average rate of 22.1 percent per year. The analysis shows a sharp import increase when the globalization wave began to pick up in the late-nineties. Brazil is the most dominant importer. Mexico follows suit as the second biggest importer with an unbalanced relation that explains its growing trade deficit. Chile is at midpoint with respect to the other countries. The buoyant importing flow will likely reach a plateau given the limited purchasing power among Latin American countries and the fact that China can reorient its multilateral trade with aims other than commercial ones. Overall, Latin America still maintains a trade surplus with China mainly due to increased commodity prices.

\section{ANALYTICAL FRAMEWORK}

The following two-sector economic model formally assumes the optimality of resource allocation as a source of growth. It uses the non-tradable sector ${ }_{N T}$ which produces intermediate and final goods and services for the domestic market and the tradable sector ${ }_{x}$ which produces exportable goods and services. As López [23] has shown, sectoraloutput is a function of capital and labor allocated to each sector as well as technology. Furthermore, output in the non-tradable sector depends on the export volume to represent the spillover effects that encourage investment and rationalize production throughout the economy.

$$
Q=Q_{N T}\left(\left(K_{N T}, L_{N T}, Q_{X}\right)+Q_{X}\left(K_{X}+L_{X}\right), T\right)(1)
$$

A multi-product profit function model under competitive equilibrium and profit maximization conditions is defined as:

$$
\Pi^{e}=\Pi^{e}\left(P^{e} ; Q, K, L, T\right)
$$


where the vector of expected output and input prices $\boldsymbol{P}^{\boldsymbol{e}}$ breaks down into non-tradables $\boldsymbol{P}_{N T}$, importables $\boldsymbol{P}_{\boldsymbol{M}}$, imported intermediate inputs $\boldsymbol{P}_{\boldsymbol{M I}}$, and exportables $\boldsymbol{P}_{\boldsymbol{X}}$. Analogously, the vector of output and input quantities $\boldsymbol{Q}$ breaks down into non-tradables $\boldsymbol{Q}_{N T}$, importables $\boldsymbol{Q}_{\boldsymbol{M}}$, imported intermediate inputs $\boldsymbol{Q}_{\boldsymbol{M}}$, and exportables $\boldsymbol{Q}_{X}$. The vectors of capital stock, employment, and a technology index are denoted as $\boldsymbol{K}, \boldsymbol{L}$, and $\boldsymbol{T}$, respectively. Subsequently, the set of fixed production factors is generically represented as $\boldsymbol{Z}$, while the set of exogenous ones is signified by $\boldsymbol{W}$.

The well-behaved profit function (2) is homogenous of degree one in prices to allow for its normalization in any chosen real price unit $\boldsymbol{P}^{\boldsymbol{e}}$. It is also twice continuously differentiable, convex, and linearly homogeneous in capital and labor under constant returns to scale to be expressed in ratio terms. A profit-maximizing equilibrium level at market prices $\boldsymbol{P}^{\boldsymbol{e}}$ is obtained by the partial derivatives of $\boldsymbol{\Pi}^{\boldsymbol{e}}$ with respect to expected output and input prices $\left(\boldsymbol{P}_{i}: i=1,, n\right)$ :

$$
\begin{aligned}
& Q^{e}=\frac{\partial \Pi^{e}}{\partial P_{i}^{e}}=Q_{i}^{*}\left(P^{\mathrm{e}} ; Z, W\right) \\
& \text { wherei }=1,,, n .
\end{aligned}
$$

The specification of (3) as an extended multi-product normalized quadratic profit function allows for the empirical estimation of local second-order approximations to an arbitrary class of flexible functional forms. The risks of imposing restrictive assumptions with respect to homotheticity and separability between factor proportions and output rate have been acknowledged extensively [24-26]. However, the advantages of the extended multi-product normalized quadratic profit function of attaining global convexity if it is locally convex are twofold: first, it yields simple linear supply and demand functions of relative prices that have real quantities or their indexes as dependent variables; and second, it facilitates the evaluation of elasticities at sample mean values of prices and quantities. Following Diewert[27], the extended multi-product normalized quadratic profit function results into:

$$
\begin{aligned}
& \Pi=\alpha_{0}+\sum_{i} \beta_{i} P_{i}+\sum_{j} \gamma_{j} Z_{j}+\sum_{k} \delta_{k} W_{k} \\
&+\frac{1}{2}\left[\sum_{i} \sum_{i^{\prime}} \varepsilon_{i i^{\prime}} P_{i} P_{i^{\prime}}+\sum_{j} \sum_{j^{\prime}} \epsilon_{j j^{\prime}} Z_{j} Z_{j^{\prime}}\right. \\
&\left.+\sum_{k} \sum_{k^{\prime}} \zeta_{k k^{\prime}} W_{k} W_{k^{\prime}}\right] \\
&+\sum_{i} \sum_{j} \eta_{i j} P_{i} Z_{j} \\
&+\sum_{i} \sum_{k} \theta_{i k} P_{i} W_{k} \\
&+\sum_{j} \sum_{k} \vartheta_{j k} Z_{j} W_{k}(4)
\end{aligned}
$$

where $\quad \Pi=\Pi^{e} / P_{0}^{e} \quad ; \quad P_{i}=P_{i}^{e} /$ $P_{0}^{e} ; \alpha, \beta, \gamma, \delta, \varepsilon, \epsilon, \zeta, \eta, \theta$, and $\vartheta$ for all $\forall i, j, k$, are unknown parameters. Application of Hotteling's lemma allows the first derivatives of (4) with respect to output and input prices to specify the output-supply and input-demand equations. Thus, such a system of linear equations is analytically derivable and generically represented in positive terms to represent an output-supply equation and in negative terms to represent an input-demand equation as:

$$
\begin{aligned}
& \stackrel{ \pm}{-} Q_{i}=\frac{\partial \pi}{\partial P_{i}}=\beta_{i}+\sum_{\mathrm{i} *} \varepsilon_{i i^{\prime}} P_{i^{\prime}}+\sum_{j} \eta_{i j} Z_{j}+ \\
& k \theta i k W k+\mu i
\end{aligned}
$$

\section{EMPIRICAL ESTIMATION}

This section presents the estimated results obtained from an extended multi-product normalized quadratic profit function from which the sources of growth are derived. It provides a comprehensive representation of the revenue structure of the various Latin American economies as a function of input and output prices, production factors, as well as other exogenous variables. Such a methodology has been widely used elsewhere to evaluate market responsiveness, spatial resource allocations, or trade efficiency aspects.

The statistical information by country between 1984 2008was obtained from various sources. The United Nations Commodity Trade - Statistics Database, the International Monetary Fund - World Economic Outlook Database, and theCentral Banks were the most useful. Missing or extraneous figures were completed or refined with information coming from other National Statistics Agencies, including the National Bureau of Statistics of China Customs Statistics Database[28]. The extended normalized quadratic profit function is individually estimated using annual data for each of the six Latin American countries.

The signs for the own-price elasticities are theoretically consistent throughout in terms of output response to price changes and factor utilization. They suggest upward-sloping output-supply and downward-sloping input-demand functions, which concur with the convexity properties of the profit function. These own-price elasticities are statistically significant at the 5-percent level, with the exception of importables, capital, and labor, which are marginally significant at values lower than 10 percent. Their magnitude indicates that they are all inelastic. Output-supply elasticities present values that fluctuate from 0.18 for non-tradables to 0.70 for importables, while input-demand elasticities show values between -0.32 and -0.64 for capital and labor, respectively.

The expected production substitutability between the tradable and non-tradable sectors was confirmed by their signs. However, $\rho$-values of 0.33 and 0.34 for exportables and importables render them as being not statistically significant. The estimated cross-price elasticities between capital and labor validate a substitutability condition that reinforces the input convexity of the profit function. Their prices negatively influence the demand for labor and capital, at least at the 10percent level of statistical significance. The existing levels of 
capital and labor exert positive effects on the production of exportables and non-tradables, with average estimated crossprice elasticities of 0.24 and 0.39 , respectively. Both results confirm the various input intensities with which the production of exportables and non-tradables takes place. Along these lines, López [23] found that under a mildly distorted trade scenario, production of exportables is relatively more capital intensive than production of nontradables and final import substitutes, which are more labor intensive. Similarly, substitutability appears between capital and imported intermediate inputs in the production of nontradable inputs. Lederman et al. [4] further examined these factor intensities in their relation to the specialization pattern pursued by China to compete globally. Acknowledging some heterogeneity across regions, they concluded that Latin American countries exploit comparative advantages in sectors that are intensive in natural resources and scientific knowledge over comparative disadvantages in sectors where skilled and unskilled labor is required.

Priceelasticities for exportables have a minimum value of 0.32 for Venezuela and a maximum of 0.75 for Brazil. As expected, importables show the more elastic prices, falling within a 0.39 - 1.05 spread for Argentina and Venezuela, respectively. Priceelasticities for imported inputs have intermediate values that fluctuate between 0.16 for Argentina and 0.59 for Brazil. Price elasticities for non-tradables are the most inelastic and vary from 0.12 for Brazil to 0.17 for Venezuela. These results correspond with Blecker and Razmi [1] as relative prices of tradables move towards long-term purchasing power parity especially for commodity exporter Latin American countries that face moderately high capitallabor ratios and relatively price-inelasticdemands.

The end points 1984 and 2008 offer a reasonably extended time to observe output fluctuations around their optimal long-run values. The average price responsiveness to exportables $\boldsymbol{P}_{X}$ of 0.57 confirms that Latin American economies are highly dependent on the growing market expansion experienced by China. Such a very large contribution falls within a $0.47-0.68$ range for Venezuela and Chile and reaffirms the need to consolidate a more sophisticated industry capable of adding value products of interest to China. As expected, price responsiveness to importables $\boldsymbol{P}_{\boldsymbol{M}}$ is negative and averages at -0.18 from a range of -0.26 to -0.12 for Chile and Mexico. Intermediate importables $\boldsymbol{P}_{\boldsymbol{M I}}$ also have negative price responsiveness that average at -0.09 , with -0.13 and -0.04 as extreme values for Brazil and Peru. Price responsiveness to non-tradables $\boldsymbol{P}_{N T}$ is negative, with a -0.02 average from within a range of -0.03 to -0.01 for Peru and Venezuela. The large spread of negative values for importables uncover the foreign trade strategy pursued by China to penetrate markets using its sheer power instead of relying exclusively on countryspecific free trade liberalization agreements to lower the impact of antidumping measures on low-cost imports.

Price responsiveness to capital $\boldsymbol{P}_{\boldsymbol{K}}$ averages at -0.07 from within a range of -0.10 to -0.05 for Mexico and Chile. Price responsiveness to labor $\boldsymbol{P}_{\boldsymbol{L}}$ is negligible across countries except for Venezuela with a meager -0.01 percent. Capital $\boldsymbol{K}$ turns out to be the second most robust growth determinant for Latin America, after the price of exportables $\boldsymbol{P}_{\boldsymbol{X}}$, with a
0.52 average and Venezuela as its most relevant country. Labor Lexplains 0.23 of the growth held by the region, with Brazil and Peru having extreme values of 0.17 and 0.29 , respectively. Approximately, a 0.28-point growth in Latin America can be attributed to technical change $\boldsymbol{T}$, with Chile, Mexico, and Brazil being the most notable with values above 0.35 . The exchangerate stability reflects its importance as a policy enhancing growth in open economies, explaining a 0.15 average growth from within a range of $0.08-0.23$ for Chile and Venezuela. The relatively low values obtained for Chile and Mexico seem counterintuitive as these countries have deliberately maintained slightly appreciated real exchange rates resulting in higher and more prolonged output accelerations than others. The negative growth impact during the 1984 - 1990 sub-period markedly offsets later effects and averages at -0.38 , with a range of -0.34 to -0.46 for Chile and Argentina.

The above findings are consistent with Cui et al. [29], and Guo and N'Diaye[30] in that a 1-percent increase in China's GDP requires an import expansion between 0.10 and 0.22 percent. Alternatively, if Latin America remained as dependent on their exports to China as it was between 1984 to 2008, a 1-percent annual grow in Latin America's GDP would only be sustained if its export share to China increased by about 0.12 percent per year. A sensitivity analysis using a 10 -percent variation in the various price-demand elasticities leaves the above conclusions qualitatively unchanged. These results also underline the fact that productivity-enhancing structural reforms play a role in explaining foreign demand as a source of economic growth. Differences in the types of cost reductions that increase efficiency in the use of production factors across Latin American countries hint towards a qualitatively sound institutional environment. Hence, policies that foster economic growth cannot neglect issues such as government effectiveness, macroeconomic stability, and human capital formation to attract foreign investment, promote competitiveness, and facilitate technical innovation.

\section{CONCLUSIONS}

The long-term economic sustainability of Latin America is at risk given its increasing export dependency on China. An overly pessimistic slowdown in China's domestic demand may not be a realistic scenario considering that past global financial crises barely scathed its growth rate at a time when developed countries floundered. Nevertheless, Latin America needs to rebalance its sources of economic growth by developing a set of export-led policy reforms that will lessen volatile commoditization. It has reached a point in its production possibilities frontier where it is not feasible to further increase its level of output unless technology and innovation come into play. Latin America must broaden its productivity base, move into more sophisticated endeavors, and diversify its export basket to gain market share.

Exotic agricultural products may carry greater weight in future bilateral or multilateral trade relations with China. Economic rise and win-win regional trade agreements could also allow Latin American countries a condition of privileged collaborators. However, these strategic options may not create further trade and instead generate tensions 
among interest groups, for example. A new trade specialization pattern needs to unveil the shrinking trade balance and position Latin America as a provider of manufactured products without its losing domination over traditional goods. This strategic relation would be strengthened if governments commit to diversifying their exporting model and promoting ways to empower traditional sectors, eliminating remnants of protectionism, and strengthening their initiatives in regional integration, as well as fostering open alliances between Latin American and Chinese enterprises in alternative industries and markets.

\section{REFERENCES}

[1] Blecker, R. and A. Razmi, "Export-led Growth, Real Exchange Rates and the Fallacy of Composition in M. Setterfiled", (Ed.) Handbook of Alternative Theories of Economic Growth. Edward Elgar, United Kingdom and United States, 2009.

[2] López-Córdova, E., A. Micco, and D. Molina,2008,How Sensitive are Latin American Exports to Chinese Competition in the U.S. Market? Economía. Vol. 2: 117-145.

[3] Arroba, A., R. Avendaño, and J. Estrada, "Adapting to the Rise of China: How Can Latin American Companies Succeed?" OECD and World Economic Forum, 2008.

[4] Lederman, D., M. Olarreaga, and E. Rubiano,'Trade Specialization in Latin America: The Impact of China and India."Review of World Economics. Spring Vol. 144(2): 248-271,2008.

[5] Lall, S., J. Weiss and H. Oikawa, "China's Competitive Threat to Latin America: An analysis for 1990-2002."Oxford Development Studies. Vol. 33(2): 163-194,2005.

[6] Gallagher, K. and R. Porzecanski, "The Dragon in the Room: China and the Future of Latin American Industrialization". Palo Alto Stanford University Press, 2010.

[7] Ellis, R., "China in Latin America: The Whats and Wherefores." Lynne Rienner Publishers Inc. Colorado - United States,2009.

[8] Easterly, W., N. Loayza, and P. Montiel, "Has Latin America's PostReform Growth Been Disappointing?"Journal of International Economics, Supplement. Vol.43(3-4): 287-312,1997.

[9] Akin, C. and M. Kose,"Changing Nature of North-South Linkages: Stylized Facts and Explanations". Journal of Asian Economies. Vol. 19: 1-28,2008.

[10] Hanson, G. and R. Robertson, "China and the Recent Evolution of Latin America's Manufacturing Exports." In China's and India's Challenge to Latin America: Opportunity or Threat? Edited by D. Lederman, M. Olarreaga and G. Perry. Washington D.C.: The World Bank,2009.

[11] Iacovone, L., F. Rauch, and A. Winters, "Trade as Engine of Creative Destruction: The Mexican experience with Chinese competition." London School of Economics: CEP Discussion Paper No 999,2010.

[12] Bloom, N., M. Draca, and J. Van Reenen, "Trade Induced Technical Change? The Impact of Chinese Imports on Innovation, IT and Productivity”. NBER Working Paper 16717, 2011.
[13] International Monetary Fund,World Economic Outlook Database,2009.

http://www.imf.org/external/pubs/ft/weo/2009/02/weodata/index.aspx

[14] Feenstra, R. and A. Rose, "Putting Things in Order: Patterns of Trade Dynamics and Product Cycles."Review of Economics and Statistics. Vol. 82: 369-382,2000.

[15] Hausmann, R. and D. Rodrik, "Economic Development as SelfDiscovery". Journal of Development Economics. Vol. 72: 603633,2003.

[16] Fernández, A. and B. Hogenboom, "Latin America and China under Global Neoliberalism."Journal of Developing Societies. Vol. 23(4): 467-501,2007.

[17] Rodrik, D., "What's So Special about China's Exports?" NBER Working Paper Series No 11947,2006.

[18] Li, K. and X. Wang, "China's Foreign Trade: Trends and Issues after WTO accession" in China's Integration with the Global Economy. C. Chunlai (Ed). Edward Elgar, UK and USA,2009.

[19] de PaivaAbreu, M., "China's Emergence in the Global Economy and Brazil.”Working Paper 491. Pontificia Universidade Catolica - Rio de Janeiro. Brazil,2005.

[20] Soloaga, I., M. Olarreaga, and D. Lederman, "The Growth of China and India in World Trade: Opportunity or Threat for Latin America and the Caribbean?", World Bank Policy Research Working Paper Series WPS 4320,2007.

[21] Jenkins, R., E. Peters, and M. Moreira,'The Impact of China on Latin America and the Caribbean."World Development. Vol. 36. 235253,2008 .

[22] Gottschalk, R. and D. Prates, "East Asia's Growing Demand for Primary Commodities - Macroeconomic Challenges for Latin America." UNTACD. G-24 Discussion Paper Series,2006.

[23] López, R., "Microeconomic Distortions: Static Losses and their Effect on the Efficiency of Investment." No 665. Policy Research Working Paper Series. The World Bank. Washington D.C.,1991.

[24] Lau, L., "A Characterization of the Normalized Restricted Profit Function."Journal of Economic Theory. Vol. 12 (1): 131-163,1976.

[25] López, R., "Structural Implications of a Class of Flexible Functional Forms for Profit Functions."International Journal of Economic Review. Vol. 26(4): 593-601,1985.

[26] Devlin, R., A. Estevadeordal and A. Rodriguez-Clare.,"The Emergence of China. Opportunities and Challenges for Latin America and the Caribbean". (Eds). Washington, DC: Inter-American Development Bank, 2006 .

[27] Diewert, W. and T. Wales,"Flexible Functional Forms and Global Curvature Conditions". Econometrica. Vol. 55(1): 43-68,1987.

[28] National Bureau of Statistics of China - Customs Statistics, 2010. http://www1.customs.gov.cn/Default.aspx?tabid=2453\&morenodulei $\mathrm{d}=3760 \&$ moretabid $=4370$.

[29] Cui, L., C. Shu, and X. Su, "How Much Do Exports Matter for China's Growth?"China Economic Issues. No 1. Hong Kong Monetary Authority,2009.

[30] Guo, K and P. N'Diaye,'Is China's Export-Oriented Growth Sustainable?" International Monetary Fund. Working Paper 172. Washington D.C,2009. 